\title{
Vascoda and the Subject-based Gateways - the German Answer to Visibility and Accessibility in Collection Development
}

by KLAUS KEMPF

\section{VISIBILITY AND ACCESSIBILITY AS INTEGRAL PARTS OF COLLECTION DEVELOPMENT?}

The „classic tasks“ of academic libraries comprise acquisition, cataloguing, reader services and preservation of literature or, more generally speaking, information resources. This has not changed radically in the digital age. What has changed, though, is the way the tasks are related to each other, perhaps also their respective importance (depending on the library type); but particularly the accentuation of certain aspects of the tasks mentioned above. Visibility and accessibility would hardly have been associated with collection development in the past. Holdings were entered in the catalogue and thus made 'visible'. Accessibility was taken care of in the reader services department. This has changed significantly in the digital age. The reasons for that are manifold:

- With the emergence of the so called 'hybrid library' the respective tasks of the central library functions have somewhat shifted and the previously rather clear-cut separations between them have become less rigid.

- The innate 'immateriality' of digital resources requires a different approach to the topic of visibility and accessibility as early as the actual point of acquisition and in the presentation and 'documentation' of collection development.

- Last but not least digital access points, next to the catalogue or OPAC including a large variety of different options (e.g. websites), have led to a much quicker and easier way of making holdings and particularly new acquisitions visible than would have been possible in the days of paper or card catalogues.

But there are more basic reasons for the new way of dealing with visibility and accessibility. This is certainly due to the characteristics of collection development in the digital age which require us 'acquisitions people' to look at the question of visibility and accessibility from a different perspective and regard these as key aspects of the work we do.

\section{ESSENTIALS OF COLLECTION DEVELOPMENT IN THE DIGITAL AGE [1]}

In contrast with the acquisition of printed literature, the library acquires digital information resources, i.e. databases, ejournals and nowadays also e-books not so much as their property, but very often only as a licence for a limited period of time and/or for a limited number of concurrent users. This new principle - access versus ownership - has quite significantly led to a newly oriented acquisitions behaviour of libraries. More than ever the question of real usage (during the licence period) on the basis of relevant statistics plays a decisive role in the acquisition and/or renewal process of digital resources.

The aspect of cooperation with other libraries, but also with other information providers, in the sense of shared collection development has gained higher significance than was the case in the past. This is partly due to the fact that the emergence of digital information coincides with the long-lasting budget crisis of academic libraries of almost all countries with a so-called developed library system. But irrespective of this aspect, all the digital information options and access points form an excellent basis for close cooperation, including shared collection decisions. The kind of visibility possible and the transparency of the acquisition process constitute a major advantage, and for some partners perhaps the reason why they enter into such cooperation. (Let me remind you at this point of the quite advanced situation in the United States where - based on digital catalogues and information tools - even so-called shared/cooperated approvals are in place.) For our topic this means that the aspect of visibility has to play a major role in collection development and acquisition processes. 
Another important aspect is a very strong focus on the end-user, that is decision-making in collection development aims at the actual usage of information resources. This is even true for libraries whose collection development principles have traditionally been quite independent from daily use, but who have rather concentrated on a long-term acquisitions policy. The one does not exclude the other in the days of the hybrid library. What is true for print is not necessarily true for digital resources. Digital resources - if they are not subscribed to continuously - are not automatically lost for the non-subscription period. The overall orientation is much closer to the 'just in time' than to the 'just in case' concept.

\section{OPTIMUM VISIBILITY AND ACCESSIBILITY: A CRUCIAL QUALITY CRITERION}

It is of crucial importance to take into account the accessibility or rather the quality of the accessibility of any newly acquired or renewed licences for information resources. This used to be a clear topic for the cataloguing department, that is the quality of the catalogue or the catalogue entry, and perhaps also for the reader services department, that is the information desk. It did not play any role for acquisition decisions in the narrow sense. This has changed. Today, prior to the decision on the acquisition of a particular information resource, this aspect must play an important role. It could even lead to a negative decision if the question of accessibility cannot be solved to everybody's satisfaction. One must bear in mind, of course, that the question of the quality of accessibility is closely related to the type of information resource and/or the respective subject area. One could go so far as to say that every single user has his or her own quality expectations, which means that a considerable degree of personalisation has to be taken into account and that standardised services become increasingly less adequate.

\section{THE GERMAN LIBRARY SYSTEM AS A SYNONYM FOR A COOPERATIVE ACQUISITION ENVIRONMENT}

As mentioned before, the question of the visualisation of collection development is particularly important when it is done cooperatively. This is difficult to explain on a purely theoretical level. I will therefore rather resort to specific examples, and I will stick to my own country, the environment I am most familiar with. Germany is a federal country, a fact that is also mirrored in the academic library landscape of our country. Division of labour and cooperative action is therefore always of great importance with any topics and projects at the national level. Accordingly, the visibility and mutual accessibility of the respective holdings play a significant role.

Germany does not have a national library in the sense of the British Library or the Bibliotheque National de France. In Germany, long before the age of internet, the concept of the 'virtual' national library was born.[2] Numerous cooperative initiatives have developed around this core structure, in which different types of libraries take part. All of them more or less aim at cooperative collection development, and have more recently put some focus on the visibility of the holdings and on the optimisation of their accessibility. Cooperative structures are concerned with conventional material as well as with electronic media:

- The German 'Virtual National Library' is constituted by the national bibliographic centre, Deutsche Nationalbibliothek, with locations in Frankfurt am Main, Leipzig and Berlin, as well as the two historically most significant research libraries - the Staatsbibliothek zu Berlin (previously Prussian State Library) and the Bayerischen Staatsbibliothek in Munich.

- In the so called 'Arbeitsgemeinschaft Sammlung Deutscher Drucke' (AGSDD) six libraries collaborate to build a comprehensive collection of printed literature published in German-speaking countries from the beginning of letterpress printing to the present, to provide information on it, to make it accessible to the public and to preserve it for future generations.

- The Zeitschriftendatenbank or German National Serials Union Catalogue is an electronic database containing bibliographic and holding information on all types of serials in German libraries. Currently, about 1 million serials titles are listed with about 5 million entries on holdings information.

- Another indication of the federal character of the German library system is the strong regional component found in German academic libraries. In the 1970s, six regional library networks were established. The network catalogues list the library holdings of the entire regions which enhances the visibility and accessibility of these collections considerably.[3] 
- More or less based on the regional union catalogues the Karlsruher Virtueller Katalog is the biggest und the best-known German meta-catalogue. It enables users to search in all German regional union catalogues at the same time.

- Finally, in the field of manuscripts, incunabula and literary remains cooperative efforts have been underway for some time in order to create single points of access at a national level. The aim is to provide both users and librarians with better orientation and working conditions in a heterogeneous library landscape with a partly fragmented holdings situation. One example is the creation of a national incunabula catalogue (Gesamtkatalog der Wiegendrucke).

- And similarly in the field of manuscripts and literary remains with the project Kalliope and the so called Handschriftendatenbank, the German catalogue of manuscripts.

What is true for the print media is also true for the digital information resources. But we are much further advanced there. In the field of e-journals and databases, German libraries have been using two information systems, the Elektronische Zeitschriftenbibliothek EZB (Electronic Journals Library) and the Datenbank-Infosystem DBIS (Database Information System), for a number of years now, which are end-user friendly and have an intuitive design.

The University Library of Regensburg has developed the basic functionalities, the design and the technical realisation of both tools. But the cooperative tradition of German librarianship can also be seen here, i.e. the maintenance and further development of the systems is done in close consultation and cooperation with all member libraries. The Electronic Journals Library in particular has meanwhile been exported to libraries in other countries, among them the Library of Congress, which uses this tool for the user-friendly administration of its e-journals collection.

A special feature of the Electronic Journals Library is that it makes use of a special signalling system known from everyday life, the traffic light. The user as well as the librarian can thus very quickly see whether an e-journal is offered electronically at all, whether it is freely accessible on the web (green light), whether the local campus has taken out a license so that direct fulltext access is possible (amber light) or whether the local library has no access rights so that the user will have to look for a different way of getting hold of the relevant document (red light).

For the Database Information System the traffic light symbols are not sufficient, because different media types (offline, online) must be administered, which leads to a more complex rights management.

\section{THE SUBJECT SPECIALIZATION SCHEME OF THE DEUTSCHE FORSCHUNGSGEMEINSCHAFT}

Another aspect of collection development in German academic libraries, which against the background of visibility and accessibility issues has increasingly been in the focus of recent discussions, is the so called subject specialisation scheme of the Deutsche Forschungsgemeinschaft (DFG), the German Research Foundation. Our colleague, Prof. Mittler, presented the DFG in some detail last year. I would like to look into it today from the point of view of visibility and accessibility as an integral part of collection development. The last couple of years have seen significant changes there.

Let me start by briefly sketching the main principles of this long-lasting funding program of the DFG. The so-called subject specialisation scheme aims at making at least one copy of every relevant scholarly publication in the world available in Germany. This includes highly specialised and therefore probably infrequently used publications, irrespective of their language or country of origin. For almost 60 years currently approx. 70 libraries have tried to achieve this ambitious goal, which was formulated in 1949 as a post-war emergency plan in order to ensure adequate literature supply throughout the country.[4]

The collection plan as a whole has been distributed according to subjects and regions. For participation in this scheme, which libraries have taken on in addition to their respective local tasks, they receive special funding from the DFG ( $75 \%$ for relevant foreign literature, that is monographs and serials as well as microforms). It is the responsibility of the libraries to buy literature published in Germany out of their own budgets. Employing their own staff, they are supposed to acquire the relevant resources quickly, to create catalogue entries, to make the material available via interlibrary loan and to preserve it for the future. 
In order to enhance the visibility and recognition of the special collections and therefore their use by the academic community as well as to integrate digital information resources, the DFG has provided special funding for the establishment of so called subject-based gateways by special collection libraries, to be set up either on their own or in cooperation with other libraries responsible for neighbouring subjects or other information providers or interested scholars. The respective libraries are free to formulate priorities on which modules to include in such a gateway on the basis of the specific requirements of a particular subject. The DFG restricts itself to the definition of a core set of modules.

Meanwhile there are 44 such initiatives, but in quite different stages of development. Apart from projects which have only just begun or which are still at planning stage, a number of them are fully developed subject-based gateways, well-received in their respective scientific community.[5]

\section{VISIBILITY AND ACCESSIBILITY IN „CHRONICON“, THE HISTORY GATEWAY OF THE BAVARIAN STATE LIBRARY}

With the establishment of its subject-based gateway Chronicon, on History and Culture of Eastern Europe, Music, Classics and Romance Culture, the Bayerische Staatsbibliothek tries to offer an integrated and quality-controlled service. This means in particular that from the starting-point of a quality-controlled metasearch in heterogeneous data sources the user will receive information on the availability of a particular document and be directed to the document itself, ideally via a link to the full text.

This process has been realised in Chronicon, which offers access to material regarding history in several steps. The subject-based gateway consists of a number of modules and tries to take a transparent approach, that is the user of the metasearch is informed about the underlying data sources and thus knows where the search results come from. Resources, which cannot be included in the metasearch, can be addressed directly. This also relates to the databases, which have been acquired via a national licence, funded by the DFG.[6] Currently this comprises completed data collections, digital editions of (historic) reference works, highly specialised bibliographic databases and backfile collections of important journals publishers. E-books available for purchase and - currently as an exception - running journals content (for example China Academic Journals) are also part of the program.

Via the modules 'new acquisitions' with an alerting option and 'current contents', which presents in searchable form tables of contents of the most important journals for that subject, the user is always informed about the current acquisitions process of the Bayerische Staatsbibliothek.

The integrated availability search leads the user - in case of positive search hits - directly to the information which of the resources discovered can be accessed and how this can be achieved, that is via the local library, interlibrary loan, document delivery etc. Ideally the user will be directly linked - for example via SFX - to the full text of the document in question. In same cases the electronic resource is available via a pay-per-use option. We feel that products and service modules like Chronicon can lead to an almost optimal realisation of the aspects of visibility and accessibility.

And Chronicon also has an interface with vascoda. Vascoda is a relatively new and comprehensive initiative for information provision at a national level.

\section{VASCODA AS KEYSTONE OF A COOPERATIVE SYSTEM OF SPECIALIZED INFORMATION SUPPLY}

Vascoda is a multilayer initiative. The aspect of an interdisciplinary, national subject-based gateway, which is also open to users outside Germany, is only one 'face' of a project, which goes much deeper than that. It is currently funded by the DFG and the German Ministry for Research and Education. It will have to be self-sustaining in two years' time. It became a registered association in November 2005, that is a legally independent body. Members are the most important German libraries, information networks and other information providers.

Its main tasks are roughly speaking the following:

- Comprehensive search functionalities, concerning all subjects and areas of academic information. 
- Standardised and convenient access options in the sense of a one-stop shopping approach via a single gateway with integrated availability search and differenciated document access options (please note the digital rights management aspect in this context)

- Further aims relate to long-term storage of digital resources, assistance with the establishment of institutional repositories and particularly the enhancement of the visibility of the underlying subject-based gateways.

A number of working and expert groups with members from all parts of the German library and information system as well as the learned societies currently work together in order to achieve this goal.

What is available at present? The gateway as such is up and running, but still work in progress:

1. The meta search functionality is available for selected data sources from the majority of subject-based gateways.

2. This is also true for the availability search as well as

3. the integration of document delivery options provided by vascoda partners.

For components (2) and (3) vascoda is based on local or regional linking modules, that is it does not aim at the establishment of parallel system architecture.

The next step will be the change from the meta search to the so called federated search with modern search engine technology. This is another example of how vascoda will not take completely new steps here, but that it will be based on existing technology which is already used in other portals (FAST and Lucene are for example used by the Northrhine-Westfalian library network HBZ and the Technical Information Library in Hanover).

The aim is to create a vascoda search space for accelerated, high-quality and quality-ranked access to a broad range of content from many different subject-based gateways.

\section{CONCLUSION}

Let me conclude by emphasising once more that visibility and accessibility are integral parts of collection development in the digital age. It is quite clear that cooperation requires transparency and visibility. At the same time convenient accessibility is the result of a more end user driven acquisition policy. In Germany, the cooperatively organised library landscape has for some time now put particular emphasis on the aspects of visibility and accessibility in collection development as the establishment of subject-based gateways shows. And finally, vascoda could become the platform for a nationwide cooperative content acquisition policy in the digital age. The aspects of visibility and accessibility in collection development will thus gain even more importance between libraries themselves and in particular between the library and the user.

\section{NOTES}

[1] Details in Klaus Kempf: "Erwerben und Beschaffen in der "Hybridbibliothek" : Lősungsansätze der Bayerischen Staatsbibliothek“. In: Entwicklungen und Bestände. Bayerische Bibliotheken im Übergang zum 21. Jahrhundert. Wiesbaden, 2003, pp. 35-67

[2] "A single German national library remains a fiction - but three major libraries constitute the „German Virtual National Library“, cited from: Olson, Michael P.: The Odyssey of a German National Library. Wiesbaden : Harrassowitz, 1996. (Beiträge zum Buch und Bibliothekswesen ; 36), page 1.

[3] Bibliotheksverbund Bayern (BVB) -http://www.bib-bvb.de/bvb.htm, Bibliotheksservice-Zentrum BadenWürttemberg incl. Saarland und Sachsen (BSZ) - http://www2.bsz-bw.de/cms/, Hochschulbibliothekszentrum Nordrhein-Westfalen incl. Rheinland-Pfalz (HBZ) - http://www.hbz-nrw.de/, Kooperativer Bibliotheksverbund BerlinBrandenburg (KOBV) - http://www.kobv.de/deutsch/framesets/frameset ie.htm, Gemeinsamer Bibliotheksverund (GBV) of Niedersachsen, Schleswig-Holstein, Hamburg, Bremen, Sachsen-Anhalt, Mecklenburg-Vorpommern, 
Vascoda and the Subject-based Gateways - the German Answer to Visibility and Accessibility in Collection

Development

Thüringen, and the Stiftung Preußischer Kulturbesitz - http://www.gbv.de/vgm/, Hessisches

Bibliotheksinformationssystem (HeBIS) -http://hebis.rz.uni-frankfurt.de/

[4] See for more information at:

http://www.dfg.de/forschungsfoerderung/wissenschaftliche infrastruktur/lis/projektfoerderung/gefoerderte_projekte/in $\underline{\text { dex.html }}$

[5] Details are available at: http://webis.sub.uni-hamburg.de/

[6] See the press report: http://www.dfg.de/aktuelles_presse/pressemitteilungen/2005/presse 2005 21.html

\section{WEB SITES REFERRED TO IN THE TEXT}

AGSDD - Arbeitsgemeinschaft Sammlung Deutscher Drucke. http://www.ag-sdd.de/

Bayerischen Staatsbibliothek. http://www.bsb-muenchen.de/

Chronicon. http://www.chronicon.de/

Deutsche Nationalbibliothek. http://www.ddb.de/

DFG - Deutsche Forschungsgemeinschaft (DFG. http://www.dfg.de/

EZB - Elektronische Zeitschriftenbibliothek. http://rzblx1.uniregensburg.de/ezeit/index.phtml?bibid=AAAAA\&colors=7\&lang=en

Handschriftendatenbank. http://www.manuscripta-mediaevalia.de/

Gesamtkatalog der Wiegendrucke. http://www.gesamtkatalogderwiegendrucke.de/

Kalliope. http://kalliope.staatsbibliothek-berlin.de/

Karlsruher Virtueller Katalog. http://www.ubka.uni-karlsruhe.de/kvk.html

Staatsbibliothek zu Berlin. http://staatsbibliothek-berlin.de/

Vascoda. http://www.vascoda.de/

Zeitschriftendatenbank. http://www.zeitschriftendatenbank.de/index.html 